\title{
Quis Custodiet Ipsos Custodes? Civilian Control over the Military*
}

\author{
Timothy Besley \\ James A. Robinson \\ LSE and CIFAR Harvard University and CIFAR
}

October 26, 2009

\section{Introduction}

In The Republic, Plato posed an essential problem of the state. Having suggested that a guardian class be nominated to protect the polity, the key question was "who will guard the guards?" (Quis custodiet ipsos custodes?). Plato's proposed solution to the problem was based on inculcating values so that the guardians would develop a distaste for power, maintaining the integrity of civilian rule. However, subsequent history suggests that this strategy has either not been tried, or that it has been less than a universal success. During the 20th centuries Latin American countries such as Argentina, Brazil, Chile and Peru were run for long periods of time by military dictatorships, and this has also been true for much of Sub-Saharan Africa since independence, for example in Ghana, Nigeria, Sierra Leone and Sudan and also in Asia, for instance in Pakistan.

The question of who guards the guards is intimately connected with broader questions of state capacity and the establishment of a monopoly of violence in society, something which Max Weber viewed as the defining feature of the modern state. But to establish such a monopoly, civilian rulers

\footnotetext{
*The authors are grateful to members of the Institutions, Organizations and Growth Group of CIFAR for comments on a preliminary presentation of these ideas and to Gabriel Leon for comments on an earlier draft of this paper. Both authors thank CIFAR for financial support and Besley also thanks the ESRC for financial support.
} 
need not only to build an effective military, but also to control it. In this paper we study how governments may solve this problem when they recognize that their decisions to build a strong army may have ramifications for subsequent coups.

In thinking about a plausible solution, and how in reality civilian governments control the military, there are some interesting empirical puzzles. For example, a natural conjecture might be that the larger and more powerful the military, the greater the threat it would be to civilian governments. Yet, in fact in countries such as the United States, Britain or France, with powerful militaries, politicians seem to have complete control and it is very hard to imagine the military mounting a coup or attempting to directly influence policy. However, there are also countries, such as Colombia, where small and ineffective militaries have hardly ever intervened in politics (Robinson, 2007). This suggests that there may be multiple ways for civilian politicians to solve the problem.

The influence of the military has been greatly neglected by economists. Most work on democracy and dictatorship (e.g., Acemoglu an Robinson, 2006) has abstracted from the role of the military. Moreover, while economists have recently begun to understand the importance of state capacity for development (Besley and Persson, 2009), they have barely studied the establishment of the monopoly of violence as part of this. Yet in some sense this is the sine qua non for other aspects of capacity, such as fiscal or bureaucratic capacity. In addition since civil wars are the consequence of the absence of the monopoly of violence, this aspect of state capacity leads directly to insecure property rights and underdevelopment (see Besley and Persson, 2008).

This discussion underlines the importance of bringing these issues into political economy models. This paper develops a simple model of the interaction between government and the military when there is the possibility of the military choosing to seize power in a military coup. The main focus here will be on how the level of resources devoted to the military is determined and what forces lead different societies to choose different outcomes. ${ }^{1}$

\footnotetext{
${ }^{1}$ Our research complements recent work by Collier and Hoeffler (2006) and Leon (2009) on the military's impact on politics and Acemoglu, Robinson and Santos-Villagran (2009) on the political economy of the monopoly of violence. It is most closely related to Acemoglu, Ticchi and Vindigni (2009a,b) which also look at the causes and consequences of having a persistently weak military.
} 


\section{The Model}

There are two time periods and no discounting. A (civilian) government is in power at the beginning of period one and has access to resources $R$. The number of citizens in the army is treated as a continuous variable $A \in[0, N]$ where $N$ is the number of competent citizens who might be called upon to serve. In period one, the government chooses the size of its army. This yields a benefit of $G(A)$ over the two time periods where $G(\cdot)$ is strictly increasing and strictly concave. These are the benefits which flow from establishing a monopoly of violence in terms of greater ability to enforce laws and provide public goods. They may also represent returns to aggressive use of the army against other countries or defense against external aggression. We would expect $G(A)$ to be highest in a situation where the country faces an external threat. Funding the army costs $w_{t} A$ per period with $t \in\{1,2\}$ indexing time. We will interpret this purely as a wage paid to each soldier and examine situations both where the civilian government can and cannot commit to $w_{2}$.

The residual resources from $R$ are spent by the government on either public goods or private transfers. We will suppose that there are spillovers, measured by $\lambda$, which mean that the army get benefits from this public spending. If $\lambda=1$, we can think of this as spending on public goods that are of interest to the army, while $\lambda=0$ is the case where all residual spending is on private transfers to the government core supporters or elites. In a crude way, this parameter will capture the conflict of interest between the government and army over the free cash flow that can be allocated. We will refer to it as the congruence parameter.

At the end of period one, the army can choose to mount a coup in which case it holds power in period 2. The total cost of a coup is $\delta(A)$. We make the following assumption on this technology.

Assumption 1: The function $\delta(A)$ is strictly decreasing and concave with $\lim _{A \rightarrow 0} \delta(A)=\infty$.

Thus mounting a coup is cheaper when the army is bigger. The final part says that a coup gets prohibitively expensive if the army is very small.

To summarize, the timing/structure is as follows: (1) The government chooses the size of the army, $A$, and the period one wage $w_{1}$. (In the commitment case, it also chooses $\left.w_{2}.\right)$; (2) Period one consumption takes 
place; (3) The army decides whether to stage a coup - if it does then it picks the period two wage $w_{2} ;$ (4) If there is no coup, then the original government remains in power and in the no commitment case chooses $w_{2}$; (5) Period two consumption takes place.

\subsection{The Coup Constraint}

Each member of the army has an outside option of $\omega$ in each period. We assume that the army maximizes its joint surplus. This abstracts from an array of issues that merit treatment including how armies deal with collective action problems in situations where there are conflicts of interest within the army. $^{2} \quad$ If the army wins power in period two, it can capture the office holding rents $R$. If it remains out of power, its payoff is $A w_{2}$, i.e. its total wages. $^{3}$ It is clear from this that the army will mount a coup if and only if $R-\delta(A) \geq \lambda\left(R-A w_{2}\right)+A w_{2}$. The first term is the total net benefit to the army of the coup. This is compared to the benefit the army gets from the democratically chosen public good, $\lambda\left(R-A w_{2}\right)$, plus the total wage payments they would get under democracy, $A w_{2}$. This inequality implies,

$$
R-\frac{\delta(A)}{1-\lambda} \geq A w_{2}
$$

For the analysis that follows, it is useful to define $\underline{A}$ as the lowest value of $A$ for which:

$$
R-\frac{\delta(\underline{A})}{1-\lambda}=\underline{A} \omega .
$$

This is the smallest size of army for which the coup constraint is satisfied when soldiers are paid their reservation wage.

Assumption 1 implies that if it exists, then $\underline{A}$ is strictly positive and is unique. For any army size below $\underline{A}$, the government is not constrained by the threat of a coup. In cases where there is no $\underline{A}$ which satisfies (2), we set $\underline{A}=N$. As the congruence parameter $\lambda$ goes to one then $\underline{A}=N$ for sure.

\footnotetext{
${ }^{2}$ This is obviously relevant in many contexts. For example, the military coup initiated by Flight Lieutenant Jerry Rawlings in Ghana in 1979 was one of junior officers against an existing military regime and led to previous military rulers Acheampong, Afrifa and Akuffo being executed.

${ }^{3}$ We could also view the army as citizens who earn $G(A)$. This would not make any difference to any of the calculations.
} 


\subsection{The Government's Problem}

The government optimizes its choice of army size taking the threat of a coup into account. We will contrast two cases depending on whether the government can commit to $w_{2}$. We discuss interpretations of this below.

The government's payoff from having an army of size $A$ if it stays in power is:

$$
G(A)+2 R-\left(w_{1}+w_{2}\right) A .
$$

This is the sum of the utility from the army, its office holding rents minus the wage bill of the army. If it were to lose power, it would be: $G(A)+R-w_{1} A$. In this case, it earns no rent in period two, but does not have to fund the army either. ${ }^{4}$

Whenever (1) holds, it is easy to check that the government prefers to be in power. So we will focus solely on situations where there is no coup in equilibrium. The question is how the government achieves this outcome. To introduce the more realistic possibility of a coup, we could introduce a stochastic component into the coup cost function as in Acemoglu and Robinson (2006).

\section{Analysis}

The government chooses the triple $\left\{w_{1}, w_{2}, A\right\}$ to maximize (3) subject to (1) and $w_{t} \geq \omega$ for $t \in\{1,2\}$.

As a benchmark consider what happens when (1) is not an issue. In this case the optimal army size $A^{*}$ solves

$$
G^{\prime}\left(A^{*}\right)=2 \omega
$$

assuming that $A^{*}<N$, i.e. the government sets the marginal benefit equal to the marginal cost when the soldiers are paid their reservation wage.

This will also be the outcome taking (1) into account if $A^{*} \leq \underline{A}$. Our model offers an insight into when this is likely to be the case. The military will be less of threat when either (i) institutional constraints limit the willingness/ability of a government to extract rents or lead them to spend on general interest public goods (high $\lambda$ ); or (ii) resources accruing to the state are low (low $R$ ) - thus a military threat may be a particular issue in resource

\footnotetext{
${ }^{4}$ We have assumed that there are no public spending spillovers from military rule.
} 
rich countries; or (iii) outside opportunities in the market are good, $\omega$ is high, in which case the government is compelled to compensate the military well.

This offers some insight into why more advanced economies and strongly institutionalized democracies in the world may be able to spend large amounts on the military without a serious threat of a coup. These tend to have strong institutions that encourage governments to spend public resources on broad based public programs rather than on narrow sectional interests.

The more interesting case is where $A^{*}>\underline{A}$, i.e. at the government's preferred size of army there will be a coup. In this case, the constraint (1) will have a real impact on the choice of military power.

If the government cannot commit to a period two wage for the army, then $w_{2}=\omega$, i.e. the government will always set the lowest feasible wage. In this case, the only way in which the government can survive in office is to reduce the size of its army to prevent the army being too powerful. When coups are relatively cheap, this will mean having a "tin pot" military which is docile because it is so weak. We record this result as:

Result 1: (Tin pot military) When the government cannot commit, then $A=\underline{A}$, i.e. the only option for the government is to have a military that is weak enough to prevent a coup.

A government with commitment power has another option. It could buy off the military with a higher period two wage. This is a world where the army is given favorable treatment, i.e. given some share of the rents that it would capture through a coup. This is only worth doing when the army size can be increased through this strategy. So the model predicts that when the coup constraint (1) binds, we should see a positive correlation between wages and army size.

Substituting (1) into (3), the government will choose the army size in this case to maximize:

$$
G(A)+R-\omega A+\frac{\delta(A)}{1-\lambda} .
$$

Assumption 1 guarantees that (4) is a concave function of $A$. We denote the solution to this maximization as $\bar{A}$. The cost in period two of having a large army is now set by the coup cost since the army has to be compensated for not holding a coup. This implies that a larger army will have to be paid a higher wage since the coup cost is smaller.

The following characterizes the two possible cases that arise. 
Result 2: Suppose that the government can commit to a future wage for the military. Then it will choose an army of size $\bar{A}<A^{*}$. Moreover, $\bar{A}>\underline{A}$ if and only if

$$
G^{\prime}(\underline{A})-\omega+\frac{\delta^{\prime}(\underline{A})}{1-\lambda}>0
$$

In this case, the period two wage will be: $w_{2}=\frac{(1-\lambda) R-\delta(\bar{A})}{\bar{A}(1-\lambda)}>\omega$.

It will never be optimal to set the first best size army as the need to pay an efficiency wage increases the cost of funding an army. But it may be optimal to choose an army that is bigger than $\underline{A}$. This will be true when (5) holds, which simply says that at $\underline{A}$ the marginal benefit from increasing the size of the army is sufficiently large to make it worthwhile paying an extra wage high enough to stop a coup. In such a case the wage is the per capita share of rents to holding office less the per capita coup cost. But, even if the government can commit, it may still choose the tin pot solution from Result 1. This will happen if $G^{\prime}(A)$, i.e. there is a small demand for the military by the government, such as would be the case in the absence of a serious external threat. This is also more likely when $\delta^{\prime}(A)$ is more negative so that coup costs fall rapidly as the army grows in size.

Another interesting comparative static comes from varying $R$. Define $W(R)$ as the maximized value of $(4)$ and $W(\underline{A} \mid R)$ as the value of the politicians utility when they set $A=\underline{A}$. Then one can show that as $R$ increases $W(\underline{A} \mid R)$ increases faster than $W(R)$ - the tin pot solution becomes more attractive. Intuitively, this happens since it gets more expensive to bribe the military when $R$ is high than it does to emasculate them.

\section{Discussion}

The simple model of the last section suggests a number of things about the incentives of civilian politicians to build an army to establish the monopoly of violence. A strong army generates benefits, but the stronger it is, the easier it is for it to mount a coup and control the state. Since the members of the military are self-interested, they have an incentive to do so since this allows them to allocate state resources to themselves.

The model shows that civilian politicians may respond to this in two ways. First, they may build a big army but give the soldiers sufficient rents so that a coup will not be attractive. 
Second, they can instead cut the army down in size emaciating it so that mounting a coup become too costly. Such a tin pot army generates few benefits and will not be sufficiently strong to establish a monopoly of violence, but this outcome can be optimal for the politicians given how much they would need to pay a big army to control it. Politicians opt to remain in power with a cheap but ineffective army and the potential for civil war. ${ }^{5}$

The model suggests that tin pot armies will tend to arise when the benefits from creating an army are small and when the rents from holding power are large. The model also suggests that tin pot armies will tend to arise when politicians find it difficult to commit. While it is somewhat arbitrary to exogenously vary the ability to commit, this can capture (in a reduced form way) differences in political institutions. For instance, the fact that in many developing countries political power is not constrained by constitutional rules or elections implies a smaller ability to commit. This may be particularly true in the highly personalistic presidential regimes in Africa.

The model is useful in interpreting heterogeneity in cross-country data on military spending. For high income countries with established democracies (high $\lambda, \delta(A)$ and $\omega$ ), we should expect military spending to be at $A^{*}$ determined entirely by preferences for use of the military and funding costs. In particular, we would not expect political institutions to matter except in so far as they affect the preference aggregation leading to $G(A)$.

For weakly institutionalized governments, we would expect $A<A^{*}$. Institutions will not matter in determining which of the two solutions the government chooses in its efforts to reduce the threat of a coup. Extremely weak institutions will leave open only the tin pot solution. But institutions which make some kinds of promises to the military credible, would allow the possibility of a larger military supported by an efficiency wage. This is more likely, all else equal, when there is a strong demand for an army due to an external threat. However, only relatively strongly institutionalized countries will be able to respond to such a threat.

The model helps us to understand why it is that so many poor countries in Africa or Latin America fail to establish effective states with a monopoly of violence. For one thing, since there is relatively little inter-state conflict in these countries, and to the extent that there is there has been the possibility of benefitting from military support from super-powers, one would expect

\footnotetext{
${ }^{5}$ See Acemoglu, Ticchi and Vindigni (2009b) for an explicit analysis of weak armies and civil war.
} 
the benefits of creating a strong military to be small. This induces politicians to create tin pot militaries. Another contributing factor is the resource dependence of these countries and lack of effective constraints on civilian politicians. These factors imply that $R$ is relatively large and possibly the ability to commit low, again favoring the tin pot solution. We would argue this is part of the explanation for why African countries combine ineffective militaries, weak state capacity and a high propensity for civil war.

Further light is thrown on these cases by considering the implications of heterogeneity in the preferences of people in society. This can be captured in the model via the parameter $\lambda$. In Africa, for example, many countries are composed of people with different ethnicities and languages, and may also be geographically distinct. Different ethnic groups will have different preferences over public goods. If the army is composed of people of a different ethnicity from those who run the civilian government then this can be interpreted as lower $\lambda$ in the model. Thus an ethnic divergence between the military and politicians can help to explain the prevalence of tin pot militaries in Africa. ${ }^{6}$

The model may also cast light on why democracy is no panacea in increasing security. Introducing an elected civilian government guarantees nothing unless democracy increases either $\lambda$ or reduces $R$. This requires that checks and balances are improved and/or a government that is intent on spending on common interest public goods.

\section{Concluding Comments}

This paper has posed a central question in state formation: how can a civilian government exert control over the army? We have treated this as an incentive problem where the government optimizes relative to a coup constraint. Two potential strategies emerge which seem relevant in looking at the data. The government can maintain a very weak army which is not a threat. Or it can treat the army well, paying it an efficiency wage. Our approach is extremely simple and many avenues for developing the model suggest themselves. In a wider sense, the paper adds to a burgeoning body of work that acknowledges the need to understand the power of the state from first principles. This

\footnotetext{
${ }^{6}$ See Cox (1976) and Luckham (1974) for arguments about how the ethnic composition of the armies in Sierra Leone and Nigeria created political instability after independence and Stepan (1971) and Philip (1978) on how the differences in the socioeconomic backgrounds of soldiers and elites in Brazil and Peru helped to precipitate coups.
} 
will help in due course to understand the large degree of heterogeneity that we see in the strength of the state around the world.

\section{References}

Acemoglu, Daron and James A. Robinson (2006) Economic Origins of Dictatorship and Democracy, New York: Cambridge University Press.

Acemoglu, Daron, James A. Robinson and Rafael J. SantosVillagran (2009) "The Monopoly of Violence: Evidence from Colombia," Unpublished.

Acemoglu, Daron, Davide Ticchi and Andrea Vindigni (2009a) "A Theory of Military Dictatorships," forthcoming in the American Economic Journal: Macroeconomics.

Acemoglu, Daron, Davide Ticchi and Andrea Vindigni (2009b) "Persistence of Civil Wars," forthcoming in the Journal of the European Economic Association.

Besley, Timothy and Torsten Persson (2008) "The Incidence of Civil War: Theory and Evidence," NBER Working Paper \#14585.

Besley, Timothy and Torsten Persson (2009) "The Origins of State Capacity: Property Rights, Taxation and Policy," forthcoming in the American Economic Review.

Collier, Paul and Anke Hoeffler (2006) "Military Expenditure and the Risks of Coups d'Etats," unpublished typescript, Oxford University.

Cox, Thomas S. (1976) Civil-Military Relations in Sierra Leone, Cambridge: Harvard University Press.

Leon, Gabriel (2009) "Soldiers or Bureaucrats? Conflict and the Military's role in Politics," Unpublished STICERD, LSE.

Luckham, Robin (1974) The Nigerian Military: A Sociological Analysis of Authority and Revolt 1960-67, New York: Cambridge University Press.

Philip, George (1978) The Rise and Fall of Peruvian Military Radicals, London: Athlone.

Robinson, James A. (2007) "Un Típico País Latinoamericano? Una Perspective sobre el Desarrollo de Colombia," in James A. Robinson and Miguel Urrutia eds. Economía Colombiano del Siglo XX, Bogotá: Fondo de Cultura Económico.

Stepan, Alfred (1971) The Military in Politics: Changing Patterns in Brazil, Princeton: Princeton University Press. 